\title{
District-wise trend analysis of rainfall pattern in last century (1901-2000) over Gangetic region in West Bengal, India
}

\author{
S. Pal ${ }^{*}$, D. Mazumdar ${ }^{2}$ and P. K. Chakraborty ${ }^{3}$ \\ ${ }^{1}$ Division of Computer Applications, ICAR-Indian Agricultural Statistics Research Institute, Pusa, New Delhi-110012, \\ INDIA \\ ${ }^{2}$ Department of Agricultural Statistics, Bidhan Chandra Krishi Viswavidyalaya, Nadia-741252 (West Bengal), \\ INDIA \\ ${ }^{3}$ Department of Agricultural Meteorology and Physics, Bidhan Chandra Krishi Viswavidyalaya, Nadia-741252 \\ (West Bengal), INDIA \\ *Corresponding author. E-mail: soumen.4345@gmail.com \\ Received: February 27, 2015; Revised received: August 3, 2015; Accepted: September 23, 2015
}

\begin{abstract}
The aim of the present study was to estimate long-term trend in the amount of rainfall for Gangetic West Bengal (GWB) meteorological sub-division of India and each of the 13 districts under GWB separately. Monthly rainfall time series data of 100 years (1901-2000) were analyzed to measure monotonous trend of rainfall employing Sen's slope estimator. Statistical significance of the trend was determined using non-parametric Mann-Kendall test. An important result derived from the analysis was that the GWB sub-division and South 24 Parganas (S24P) district showed significant increasing trend (mm/year) of annual rainfall measuring 2.025 and 4.99 respectively. An inclining trend of monsoon precipitation, which was significant, found in four districts viz. Bankura, North 24 Parganas (N24P), S24P and West Midnapore along with GWB itself. A major finding of the study revealed that six districts and GWB had significant increasing trend in September rainfall with a maximum value of $1.324 \mathrm{~mm} / \mathrm{year}$ in S24P district. Contribution of rainfall in October and post-monsoon season as well increased considerably in Kolkata and S24P districts while in December, similar trend was observed for Birbhum and Howrah districts. Murshidabad, S24P and East Midnapore districts experienced significant rising trend of precipitation in July, August and November respectively. On the contrary, Burdwan and Nadia districts, in the month of May and pre-monsoon season, had considerable declining trend of rainfall. Significant decreasing trend ( $\mathrm{mm} / \mathrm{year}$ ) of precipitation, a concern for Nadia district, with magnitude of 0.127 and 0.293 , was observed in the months of March and April respectively.
\end{abstract}

Keywords: Gangetic West Bengal, Mann-Kendall test, Rainfall time series, Sen's slope estimator, Trend estimation

\section{INTRODUCTION}

Trend can be defined as long-term change in the mean level (Chatfield, 2003). Although the subject area of climate change is vast, the changing pattern of rainfall is a topic within this field that deserves urgent and systematic attention, since it affects both the availability of freshwater and food production (Dore, 2005). Hence, it is an important parameter to detect climate change and asses its impact on various sectors including agriculture, industry etc.

The last century has observed a lot of changes in climatic variables over the years in different parts throughout the world. A systematic increase of rainfall in much of the middle and high latitudes of the northern hemisphere was observed in a detailed study of surface observed global land precipitation variations during 1900-88 (Dai et al., 1997). In India, rainfall pattern in last century during different seasons indicate decreasing tendency in the summer monsoon rainfall and increasing trend in the rainfall during pre-monsoon and post-monsoon months (Dash et al., 2007). Earlier, Parthasarathy (1984) analyzed summer monsoon (June to September) rainfall series of 29 sub-divisions for 108 years period (1871-1978) and found the rainfall series of all the sub-divisions homogeneous whereas significant change in mean rainfall of six sub-divisions was noticed. Mooley and Parthasarathy (1984) found no significant long term trend in Indian monsoon rainfall. This was further confirmed by Thapliyal and Kulshrestha (1991), Srivastava et al. (1992) etc. However, due to its vast size and complex geography, climate in this country has large spatial and temporal variations. Kumar et al. (1992) found increasing trend in the monsoon seasonal rainfall along the west coast, north Andhra Pradesh and north-west India, and those of decreasing trend over east Madhya Pradesh and adjoining areas, northeast India and parts of Gujarat and Kerala. Singh and Sontakke (2002) noticed, in case of summer monsoon rainfall, decreasing trend over Central Indo-Gangetic Plain region (IGPR) from 1939; increasing and declining trend over Western IGPR from 1900 and during 1900-1984 respectively; and insignificant increasing trend during 1984-1999 over Eastern IGPR. GuhathaISSN : 0974-9411 (Print), 2231-5209 (Online) All Rights Reserved (C) Applied and Natural Science Foundation www.ansfoundation.org 
kurta and Rajeevan (2008) found that during the period 1901-2003, in case of south-west monsoon season, three subdivisions viz. Jharkhand, Chattisgarh and Kerala experienced significant decreasing trend of rainfall whereas eight subdivisions viz. GWB, West Uttar Pradesh, Jammu and Kashmir, Konkan and Goa, Madhya Maharashtra, Rayalseema, Coastal Andhra Pradesh and North Interior Karnataka showed significant increasing trends of precipitation. Kumar et al. (2010) studied monthly data series of 135 years (18712005) for 30 sub-divisions in India and found significant increasing trend of annual rainfall in Haryana, Punjab and Coastal Karnataka sub-division; major decreasing trend of precipitation in Chattisgarh; decreased annual and monsoon rainfall and increased winter rainfall at the national scale. Kumar and Jain (2011) analyzed the rainfall pattern for 22 river basins of India out of which one basin each in annual and post -monsoon, two basins in winter season showed significant increasing trend of rainfall whereas one basin in annual, three basins in pre-monsoon and two basins in monsoon season experienced considerable declining trend of rainfall. Mondal et al. (2012), after analyzing daily rainfall data from 1971 to 2010 of a river basin in Cuttack district of Orissa, found increasing trend of rainfall in the months of January, May, June, September, October and November and decreasing trend of rainfall in rest of the months. Due to such variations of rainfall across the regions, and fluctuations from one place to another, this particular climatic parameter needs to be studied meticulously at local level, such as block or district, for higher precision level.

West Bengal is an agro-based state of India. The major part of this state falls under the GWB meteorological Subdivision $(66,228 \mathrm{Sq}$. Km.). The region consists of 13 districts viz. Bankura, Birbhum, Burdwan, East Midnapore, Hooghly, Howrah, Kolkata, Murshidabad, Nadia, North 24 Parganas, Purulia, South 24 Parganas and West Midnapore. On an average, more than $75 \%$ of rainfall, in this area, is received during monsoon season. However, due to ecological and climatic differences from one place to another, the region always experiences variation in spatial distribution of precipitation. Therefore, a district-wise study, for the area, is essential to capture the true scenario of rainfall pattern over the years. The primary source of livelihood for majority of people living in this area is purely agrobased and growing of all the major crops is mainly dependent on timely occurrence of rainfall. Irrigation facilities also depend, directly (canal) or indirectly (ground water), heavily on sufficient amount of precipitation. As the region experiences, from time to time, both excessive as well as insufficient rainfall, agricultural production are often been seriously affected. A proper study on district-wise trend of rainfall is therefore needed to predict such situations in well advance and formulate effective agricultural and hydrological planning according to that. Krishnakumar et al. (2009) pointed out the possible concern for hydel power generation and water availability in Kerala during summer months due to declining trend of rainfall in June and July, which are the rainiest months of the state. At the same time, the author mentioned the beneficial aspect for majority of plantation crops due to increase in rainfall during the post-monsoon season in the state. Patle and Libang (2014) pointed out that decreasing pattern of rainfall during post monsoon season may affect the vegetable and fruit production in winter season in North-east region of India. The present study was undertaken to analyze the rainfall pattern in last century (1901-2000) over GWB subdivision and the districts under it.

Generally parametric (distribution-dependent) or nonparametric (distribution-free) statistical tests can be used to decide whether there is a statistically significant trend. In parametric testing, it is necessary to assume an underlying distribution, often the normal distribution for the data, and to make assumptions that data observations are independent of one another (Mozejko, 2012). If parametric techniques are to be used, it may be necessary to (a) transform data so that its distribution is nearly normal and (b) restrict analyses to annual series, for which independence of assumptions are acceptable, rather than using the more detailed monthly, daily or hourly data (Helsel and Hirsch, 1992). Statistical tests designed for normal distributions are often sensitive to outliers (Schertz et al., 1991). In non-parametric and distribution-free methods, fewer assumptions about the data need to be made. They are robust towards missing values and seasonal effects (Gilbert, 1987). Trend analysis of nonnormally distributed data can efficiently be performed using non-parametric Mann-Kendall (M-K) test and employing Sen's slope estimator. In the present study, the same methodology has been adopted for estimating rainfall trend. The rest of this paper is organized as follows: the next section describes the data source and methodology used to carry out the research work followed by discussion on results and finally conclusion.

\section{MATERIALS AND METHODS}

Collection of data: Sub-divisional (GWB) as well as district-wise monthly rainfall data from 1901 to 2000 was purchased from India Meteorological Department (IMD), Pune for conducting the present study (NCC Research Report, 2011). The average of all available monthly rainfall values are used to replace the observations which are missing in the time series. The observations are measured in millimeter $(\mathrm{mm})$. For seasonal analysis, each year is divided into four climatic seasons viz. pre-monsoon (March-May), monsoon (JuneSeptember), post-monsoon (October-December) and winter (January-February).

Sen's Slope Estimator: In this study, magnitude of trend in the time series is determined using a nonparametric method (Theil, 1950) known as Theil-Sen 
estimator or Sen's slope estimator (Sen, 1968). Sen's method assumes a linear trend in the time series and has been widely used for determining the magnitude of trend in hydro-meteorological time series (Mondal et al., 2012; Jain et al., 2013; Kumar et al., 2014). By using this method, the true slope (change per unit time) can be estimated by using a simple non-parametric procedure. To derive an estimate of the slope $\mathrm{Q}$ in a linear model

$$
f(t)=Q t+B \text {, }
$$

where $B$ is a constant, the slopes of all data pairs are calculated as

$$
Q_{i}=\frac{x_{j}-x_{k}}{j-k}, i=1,2, \ldots, N
$$

Where, $x_{j}$ and $x_{k}$ are data values at time $\boldsymbol{j}$ and $k \quad(j>k)$, respectively. The median of these $\boldsymbol{V}$ values of $\boldsymbol{Q}_{i}$ is Sen's estimator ( $\boldsymbol{Q}$ ) of slope, which is calculated as:

$$
Q= \begin{cases}Q_{\frac{N+1}{2}} & \text { if } N \text { is odd } \\ \frac{1}{2}\left(Q_{\frac{N}{2}}+Q_{\frac{N+2}{2}}\right) & \text { if } N \text { is even }\end{cases}
$$

A positive value of $Q$ indicates an upward (increasing) trend and a negative value indicates a downward (decreasing) trend in the time series.

\section{Mann-Kendall Test}

To determine the presence of statistically significant trend in hydrologic and climatic variables such as temperature, precipitation, and stream flow with reference to climate change, non-parametric M-K test (Mann, 1945; Kendall, 1975) was employed by a number of researchers (Yue et al., 2003; Singh et al., 2008; Kumar and Jain, 2011; Kumar et al., 2014).

The M-K test is applicable in cases when the data values $x_{i}$ of a time series, due to Salmi et al. (2002), can be assumed to obey the model,

$$
x_{i}=f\left(t_{i}\right)+\varepsilon_{i}
$$

Where, $f(t)$ is a continuous monotonic increasing or decreasing function of time and the residuals $\varepsilon_{i}$ can be assumed to be from the same distribution with zero mean and constant variance. According to this test, the null hypothesis $H_{\mathrm{o}}$ assumes that there is no trend. The alternative hypothesis $H_{1}$ is that the data follow an increasing or decreasing monotonic trend over time. The M-K statistic ( $S$ ) is computed as follows:

$$
\begin{aligned}
& S=\sum_{i=1}^{n-1} \sum_{j=i+1}^{n} \operatorname{sign}\left(x_{j}-x_{i}\right) \\
& \operatorname{sign}\left(x_{j}-x_{i}\right)=\left\{\begin{array}{r}
1 \text { if } x_{j}-x_{i}>0 \\
0 \text { if } x_{j}-x_{i}=0 \\
-1 \text { if } x_{j}-x_{i}<0
\end{array}\right.
\end{aligned}
$$

Where, $x_{j}$ and $x_{i}$ are the data values at time $j$ and $i, j>i$ respectively. If a data value from a later time period is higher (lower) than a data value from an earlier time period, the statistic $S$ is incremented (decremented) by 1 . For $n \geq \mathbf{1 0}$, the statistic $S$ is approximately normally distributed with the mean and variance as follows:

$$
\begin{aligned}
& E(S)=0 \\
& \operatorname{Var}(S)=\frac{1}{18}\left[n(n-1)(2 n+5)-\sum_{p=1}^{q} t_{p}\left(t_{p}-1\right)\left(2 t_{p}+5\right)\right]
\end{aligned}
$$

Where, $q$ is the number of tied (zero difference between compared values) groups and $t_{p}$ is the number of ties in the $p^{\text {th }}$ group. The standard test statistic $Z$ is computed as follows

$$
Z=\left\{\begin{array}{ccc}
\frac{S-1}{\sqrt{\operatorname{Var}(S)}} & \text { if } & S>0 \\
0 & \text { if } & S=0 \\
\frac{S+1}{\sqrt{\operatorname{Var}(S)}} & \text { if } & S<0
\end{array}\right.
$$

and is approximately normally distributed. The presence of a statistically significant trend is evaluated using the $Z$ value. A positive (negative) value of $Z$ indicates an upward (downward) trend. If the computed value of $|Z|>Z_{\alpha / 2}$, the null hypothesis

$\left(H_{\mathrm{o}}\right)$ is rejected at level of significance in a twosided test.

\section{Kendall's Tau}

A statistic which is closely related to $S$ in (5) is Kendall's tau (Kendall, 1975) defined by

$$
\tau=\frac{S}{D}
$$

Where,

$$
D=\left[\frac{1}{2} n(n-1)-\frac{1}{2} \sum_{j=1}^{p} t_{j}\left(t_{j}-1\right)\right]^{\frac{1}{2}}\left[\frac{1}{2} n(n-1)\right]^{\frac{1}{2}}
$$

When there are no ties in the data, (11) collapses to

$$
\tau=\frac{S}{\frac{1}{2} n(n-1)}=\frac{S}{\left(\begin{array}{l}
n \\
2
\end{array}\right)}
$$

Due to relationship between $\tau$ and $s$ in (10), the distribution of tau can be easily obtained from the distribution of $S$. It is a measure of correlation, and so measures the strength of the relationship between two variables. Kendall's tau is analogous to the correlation coefficient in regression analysis and has a range of -1 to +1 .

\section{RESULTS AND DISCUSSION}

Monthly, seasonal and annual rainfall data have been analyzed separately for GWB meteorological subdivision and the districts under it. The bold entries in Tables 1 to 4 indicate significant $Z$ value at 0.05 level and the associated magnitude of trend. A separate Table 5 is depicting the months or seasons associated with all the significant increasing and decreasing trend 
along with respective district or GWB. The results obtained from statistical analyses are discussed below.

Rainfall trend in GWB sub-division: From table 1, it is observed that in GWB sub-division, a significant monotonically increasing trend $(0.731 \mathrm{~mm} /$ year $)$ of rainfall has been detected in the month of September. For this month, a relatively high Kendall's tau value (0.198) also implies strong positive correlation between precipitation and time i.e. rainfall increases considerably as the year progresses starting from 1901. It is also found that substantial increasing trend of monsoon $(1.901 \mathrm{~mm} /$ year $)$ as well as annual $(2.025 \mathrm{~mm} /$ year) rainfall has been observed in the region. Dash et al. (2007) found similar result i.e. significant increase of summer monsoon rainfall in GWB sub-division during 1871-2002. Guhathakurta and Rajeevan (2008), for the period 1901-2003, also pointed out considerable increasing trend of annual, monsoon and September rainfall in this region. Kumar et al. (2010), after analyzing the sub-divisional monthly rainfall data of India for 135 years (1871-2005) prepared by the Indian Institute of Tropical Meteorology (IITM: htpp:// www.tropmet.res.in), mentioned significant increase $(0.35 \mathrm{~mm} /$ year $)$ of precipitation in the month of September. The same study also found increase in annual (0.95 $\mathrm{mm} /$ year) and monsoon $(0.58 \mathrm{~mm} /$ year) rainfall, however, not significant may be due to using data set and time span different from the present study.

\section{District-wise rainfall trend:}

Monsoon months and season: Tables 2 and 3 depict $\tau$ and $Z$ values obtained from M-K test and Sen's slope estimator for the monthly rainfall of the districts under GWB region. Table 4 illustrates values of the same estimates for seasonal and annual rainfall in those 13 districts. These results cannot be compared with the findings of other research works as no such study, for the district-wise rainfall trend estimation, has been done till now for the GWB sub-division. From the present study, it has been observed that in the particular month of September, 6 districts (Bankura, Birbhum, East Midnapore, Howrah, N24P and S24P) experience significant increasing trend $(\mathrm{mm} / \mathrm{year})$ of precipitation measuring $0.676,0.843,1.011,0.767$, 0.716 and 1.324 respectively. As a consequence, the total rainfall during monsoon season can also be expected to increase to some extent in those districts. In fact, out of the 6 districts, 3 districts viz. Bankura, N24P and S24P show considerable inclining trend (mm/year) of monsoon rainfall with values 1.814 , 1.864 and 4.372 respectively. A significant increasing trend (1.612 mm/year) of monsoon rainfall is also observed in West Midnapore district. The two other monsoon months, July and August observe substantial inclining trend $(\mathrm{mm} /$ year) of rainfall in Murshidabad (0.905) and S24P (0.999) districts. The June rainfall has increased in six districts, and in seven districts, it has been decreased. However, none of those trends are statistically significant.

Post-monsoon months and season:October, November and December are the 3 post-monsoon months. During this period, rainfall in some of the districts has increased significantly. In Kolkata and S24P districts, the October rainfall showed considerable inclining trend $(\mathrm{mm} /$ year) of 0.619 and 0.644 respectively. This influences significant increased trend $(\mathrm{mm} / \mathrm{year})$ of precipitation during post-monsoon season in Kolkata (0.859) and S24P (0.848) districts respectively. East Midnapore district has shown substantial increased rainfall $(0.063 \mathrm{~mm} /$ year $)$ in November. Birbhum and Howrah districts, in December, observe relatively less inclining trend of rainfall i.e. $0.001 \mathrm{~mm} /$ year, however, it is statistically significant because the amount of rainfall is itself, in general, very less in this month.

Pre-monsoon months and season: In Nadia district,

Table 1. Sen's slope (Q) (mm/year), $\tau$ and Z statistics of M-K test for monthly, seasonal and annual rainfall of GWB

\begin{tabular}{|c|c|c|c|}
\hline \multirow[b]{2}{*}{ Month } & \multirow{2}{*}{$\begin{array}{c}\text { Trend } \\
Q\end{array}$} & \multirow{2}{*}{\multicolumn{2}{|c|}{$\begin{array}{r}\text { M-K Test } \\
Z\end{array}$}} \\
\hline & & & \\
\hline January & 0.008 & 0.036 & 0.518 \\
\hline February & 0.006 & 0.009 & 0.131 \\
\hline March & -0.013 & -0.015 & -0.214 \\
\hline April & 0.051 & 0.032 & 0.465 \\
\hline May & -0.035 & -0.015 & -0.220 \\
\hline June & 0.127 & 0.024 & 0.345 \\
\hline July & 0.485 & 0.104 & 1.537 \\
\hline August & 0.389 & 0.087 & 1.275 \\
\hline September & 0.731 & 0.198 & 2.910 \\
\hline October & 0.281 & 0.087 & 1.278 \\
\hline November & 0.035 & 0.105 & 1.532 \\
\hline December & 0.000 & 0.049 & 0.683 \\
\hline \multicolumn{4}{|c|}{ Annual/Seasonal } \\
\hline Pre-monsoon & 0.041 & 0.010 & 0.149 \\
\hline Monsoon & 1.901 & 0.192 & 2.829 \\
\hline Post-monsoon & 0.340 & 0.084 & 1.230 \\
\hline Winter & 0.007 & 0.006 & 0.080 \\
\hline Annual & 2.025 & 0.156 & 2.302 \\
\hline
\end{tabular}


Table 2. Sen's slope (Q) (mm/year), $\tau$ and $Z$ statistics of M-K test for district-wise monthly (Jan-Jun) rainfall of GWB.

\begin{tabular}{|c|c|c|c|c|c|c|c|}
\hline District & Test Value & Jan & Feb & Mar & Apr & May & Jun \\
\hline \multirow[t]{3}{*}{ Bankura } & $\mathrm{Q}$ & 0.000 & -0.013 & -0.007 & 0.000 & -0.256 & 0.102 \\
\hline & $\tau$ & 0.040 & -0.027 & -0.029 & -0.003 & -0.116 & 0.022 \\
\hline & $\mathrm{Z}$ & 0.702 & -0.906 & 0.033 & 1.011 & -0.666 & 0.609 \\
\hline \multirow[t]{3}{*}{ Birbhum } & Q & 0.000 & 0.000 & -0.003 & 0.162 & -0.096 & 0.047 \\
\hline & $\tau$ & 0.032 & 0.002 & -0.014 & 0.124 & -0.035 & 0.010 \\
\hline & Z & 0.462 & 0.027 & -0.200 & 1.829 & -0.509 & 0.146 \\
\hline \multirow[t]{3}{*}{ Burdwan } & Q & 0.000 & -0.001 & -0.062 & -0.081 & -0.528 & -0.393 \\
\hline & $\tau$ & 0.038 & -0.006 & -0.083 & -0.049 & -0.222 & -0.093 \\
\hline & Z & 0.542 & -0.083 & -1.219 & -0.715 & -3.270 & -1.361 \\
\hline \multirow[t]{3}{*}{ East Midnapore } & Q & 0.000 & 0.000 & -0.008 & 0.039 & -0.008 & -0.083 \\
\hline & $\tau$ & -0.018 & 0.004 & -0.017 & 0.026 & -0.002 & -0.013 \\
\hline & Z & -0.261 & 0.063 & -0.241 & 0.378 & -0.033 & -0.194 \\
\hline \multirow[t]{3}{*}{ Hooghly } & Q & 0.000 & 0.000 & -0.035 & 0.039 & -0.004 & 0.219 \\
\hline & $\tau$ & -0.010 & 0.006 & -0.061 & 0.029 & -0.003 & 0.046 \\
\hline & Z & -0.142 & 0.086 & -0.894 & 0.426 & -0.039 & 0.667 \\
\hline \multirow[t]{3}{*}{ Howrah } & Q & 0.000 & -0.008 & 0.000 & 0.030 & -0.023 & -0.200 \\
\hline & $\tau$ & -0.006 & -0.046 & -0.011 & 0.038 & -0.025 & -0.042 \\
\hline & Z & -0.088 & -0.660 & -0.155 & 0.546 & -0.367 & -0.614 \\
\hline \multirow[t]{3}{*}{ Kolkata } & Q & 0.000 & 0.008 & -0.010 & 0.028 & -0.239 & -0.100 \\
\hline & $\tau$ & 0.052 & 0.023 & -0.021 & 0.016 & -0.071 & -0.014 \\
\hline & Z & 0.732 & 0.340 & -0.307 & 0.232 & -1.042 & -0.200 \\
\hline \multirow[t]{3}{*}{ Murshidabad } & Q & 0.000 & -0.006 & -0.024 & 0.059 & -0.185 & -0.095 \\
\hline & $\tau$ & -0.015 & -0.022 & -0.044 & 0.034 & -0.066 & -0.025 \\
\hline & Z & -0.207 & -0.325 & -0.647 & 0.503 & -0.971 & -0.363 \\
\hline \multirow[t]{3}{*}{ Nadia } & Q & 0.000 & -0.035 & -0.127 & -0.293 & -0.495 & -0.369 \\
\hline & $\tau$ & 0.025 & -0.072 & -0.161 & -0.148 & -0.140 & -0.086 \\
\hline & Z & 0.347 & -1.052 & -2.353 & -2.171 & -2.052 & -1.266 \\
\hline \multirow[t]{3}{*}{ N 24 Parganas } & $\mathrm{Q}$ & 0.000 & 0.000 & -0.049 & -0.093 & -0.164 & -0.064 \\
\hline & $\tau$ & 0.029 & 0.006 & -0.057 & -0.055 & -0.046 & -0.010 \\
\hline & Z & 0.414 & 0.089 & -0.831 & -0.810 & -0.673 & -0.143 \\
\hline \multirow[t]{3}{*}{ Purulia } & Q & 0.000 & -0.023 & 0.003 & 0.113 & -0.065 & 0.177 \\
\hline & $\tau$ & 0.003 & -0.035 & 0.019 & 0.103 & -0.030 & 0.038 \\
\hline & Z & 0.045 & -0.512 & 0.271 & 1.507 & -0.438 & 0.554 \\
\hline \multirow[t]{3}{*}{ S 24 Parganas } & Q & 0.000 & -0.002 & -0.008 & -0.026 & 0.158 & 0.085 \\
\hline & $\tau$ & 0.014 & -0.019 & -0.033 & -0.017 & 0.048 & 0.014 \\
\hline & Z & 0.192 & -0.280 & -0.474 & -0.247 & 0.700 & 0.208 \\
\hline \multirow[t]{3}{*}{ West Midnapore } & Q & 0.000 & -0.029 & 0.008 & 0.231 & 0.114 & 0.256 \\
\hline & $\tau$ & 0.000 & -0.035 & 0.016 & 0.127 & 0.036 & 0.049 \\
\hline & Z & 0.003 & -0.509 & 0.238 & 1.867 & 0.521 & 0.712 \\
\hline
\end{tabular}

rainfall in the months of March, April and May has decreased significantly measuring $0.127 \mathrm{~mm}, 0.293$ $\mathrm{mm}$ and $0.495 \mathrm{~mm}$ per year respectively. As a consequence, the rainfall during pre-monsoon season, in the district, has a substantial declining trend of $1.086 \mathrm{~mm} /$ year. Burdwan district follows similar diminishing trend $(0.839 \mathrm{~mm} /$ year $)$ of pre-monsoon rainfall accompanied by significant decreased precipitation of 0.528 $\mathrm{mm} /$ year in the month of May.

Annual rainfall: S24P is the district, which already shows significant increasing trend of rainfall in the months of August, September, October, and also in monsoon and post-monsoon season. As a result, the annual rainfall, in the district, increases extensively with a magnitude of $4.99 \mathrm{~mm} /$ year.

\section{Conclusion}

The present study concluded that the GWB subdivision and the districts under it showed substantial changes in rainfall pattern during the last century. The district-wise trend of rainfall volume, in many cases, is not same as observed for the entire GWB region. As an instance, the GWB area does not experience any declining trend of pre-monsoon rainfall, which is, however, pre-dominant in two districts. Instead, the region shows slight upward trend $(0.041 \mathrm{~mm} /$ year $)$, though not significant, during the same period. Thus the importance of trend analysis, in the scale of smaller region i.e. district in this case, is justified. The level of precision can more be improved, if the analysis would be done in block level. An interesting result, in the present study, revealed that in the month of September, 6 out of 13 districts and the GWB itself, experience significant increasing trend of rainfall during the period 1901-2000. This can lead to draw an inference i.e. rising in amount of precipitation during later part of monsoon season at least in those districts or the GWB region as a whole over the period. However, over precipitation, as observed in this particular month of September, may cause flood which is detrimental to crop 
Table 3. Sen's slope (Q) (mm/year), $\tau$ and $Z$ statistics of M-K test for district-wise monthly (Jul-Dec) rainfall of GWB.

\begin{tabular}{|c|c|c|c|c|c|c|c|}
\hline District & Test Value & Jul & Aug & Sep & Oct & Nov & Dec \\
\hline \multirow[t]{3}{*}{ Bankura } & $\mathrm{Q}$ & 0.341 & 0.475 & 0.676 & 0.234 & 0.000 & 0.000 \\
\hline & $\tau$ & 0.060 & 0.095 & 0.161 & 0.081 & 0.083 & 0.081 \\
\hline & Z & 0.882 & 1.391 & 2.362 & 1.194 & 1.180 & 1.084 \\
\hline \multirow[t]{3}{*}{ Birbhum } & Q & 0.433 & 0.290 & 0.843 & 0.270 & 0.000 & 0.001 \\
\hline & $\tau$ & 0.075 & 0.061 & 0.165 & 0.083 & 0.087 & 0.155 \\
\hline & $\mathrm{Z}$ & 1.102 & 0.890 & 2.427 & 1.227 & 1.214 & 2.049 \\
\hline \multirow[t]{3}{*}{ Burdwan } & Q & 0.146 & 0.217 & 0.447 & -0.022 & 0.000 & 0.000 \\
\hline & $\tau$ & 0.036 & 0.043 & 0.116 & -0.007 & 0.025 & 0.047 \\
\hline & $\mathrm{Z}$ & 0.527 & 0.625 & 1.712 & -0.104 & 0.348 & 0.621 \\
\hline \multirow[t]{3}{*}{ East Midnapore } & Q & -0.165 & 0.172 & 1.011 & 0.323 & 0.063 & 0.000 \\
\hline & $\tau$ & -0.027 & 0.028 & 0.211 & 0.076 & 0.137 & -0.001 \\
\hline & $\mathrm{Z}$ & -0.396 & 0.414 & 3.112 & 1.117 & 1.961 & -0.003 \\
\hline \multirow[t]{3}{*}{ Hooghly } & Q & 0.354 & 0.041 & 0.185 & 0.078 & 0.000 & 0.000 \\
\hline & $\tau$ & 0.070 & 0.011 & 0.040 & 0.028 & 0.001 & -0.011 \\
\hline & $\mathrm{Z}$ & 1.024 & 0.152 & 0.587 & 0.405 & 0.009 & -0.138 \\
\hline \multirow[t]{3}{*}{ Howrah } & Q & 0.000 & 0.204 & 0.767 & -0.009 & 0.000 & 0.001 \\
\hline & $\tau$ & 0.001 & 0.041 & 0.165 & -0.022 & 0.109 & 0.149 \\
\hline & $\mathrm{Z}$ & 0.009 & 0.590 & 2.416 & -0.313 & 1.536 & 1.975 \\
\hline \multirow[t]{3}{*}{ Kolkata } & Q & 0.598 & 0.156 & 0.639 & 0.619 & 0.000 & 0.000 \\
\hline & $\tau$ & 0.099 & 0.028 & 0.107 & 0.147 & 0.069 & 0.056 \\
\hline & $\mathrm{Z}$ & 1.453 & 0.405 & 1.575 & 2.162 & 0.982 & 0.734 \\
\hline \multirow[t]{3}{*}{ Murshidabad } & Q & 0.905 & 0.086 & 0.424 & 0.161 & 0.000 & 0.000 \\
\hline & $\tau$ & 0.146 & 0.019 & 0.080 & 0.048 & 0.054 & 0.063 \\
\hline & $\mathrm{Z}$ & 2.147 & 0.280 & 1.176 & 0.706 & 0.760 & 0.826 \\
\hline \multirow[t]{3}{*}{ Nadia } & Q & 0.331 & -0.283 & -0.312 & -0.022 & 0.000 & 0.000 \\
\hline & & 0.061 & -0.058 & -0.073 & -0.016 & -0.004 & 0.065 \\
\hline & $\mathrm{Z}$ & 0.899 & -0.858 & -1.075 & -0.238 & -0.058 & 0.858 \\
\hline \multirow[t]{3}{*}{ N 24 Parganas } & Q & 0.328 & 0.318 & 0.716 & 0.185 & 0.000 & 0.000 \\
\hline & $\tau$ & 0.057 & 0.071 & 0.156 & 0.050 & 0.034 & 0.038 \\
\hline & $\mathrm{Z}$ & 0.837 & 1.045 & 2.293 & 0.727 & 0.479 & 0.496 \\
\hline \multirow[t]{3}{*}{ Purulia } & Q & -0.618 & -0.388 & 0.547 & 0.227 & 0.000 & 0.000 \\
\hline & $\tau$ & -0.109 & -0.085 & 0.105 & 0.083 & 0.073 & 0.074 \\
\hline & $\mathrm{Z}$ & -1.599 & -1.251 & 1.552 & 1.212 & 1.029 & 0.983 \\
\hline \multirow[t]{3}{*}{ S 24 Parganas } & Q & 0.931 & 0.999 & 1.324 & 0.644 & 0.058 & 0.000 \\
\hline & $\tau$ & 0.131 & 0.159 & 0.279 & 0.137 & 0.113 & -0.032 \\
\hline & Z & 1.927 & 2.335 & 4.107 & 2.022 & 1.642 & -0.435 \\
\hline \multirow[t]{3}{*}{ West Midnapore } & Q & 0.311 & 0.340 & 0.581 & 0.009 & 0.000 & 0.000 \\
\hline & $\tau$ & 0.062 & 0.067 & 0.128 & 0.004 & -0.006 & 0.007 \\
\hline & Z & 0.917 & 0.989 & 1.879 & 0.063 & -0.078 & 0.088 \\
\hline
\end{tabular}

growth and survival. It produces stagnation of water in agricultural field, which leads to significant loss of the pre-harvested standing crops. The excessive rainfall during the post-monsoon season which is the peak harvesting time for kharif crops also produces severe yield loss. On the other side, the decreasing trend of pre-monsoon rainfall, which may be a concern for Nadia and Burdwan districts, can cause drought situation and hamper agricultural activities like land preparation particularly in nonirrigated areas. Increasing trend of rainfall during the time span of 100 years (1901-2000), prominent in the months of August, September, October, and also through monsoon and post-monsoon season, in S24P district, can pose severe threat, not restricted to agriculture. Resolutions, based on rainfall trend, is required to cope up with the changing pattern of precipitation and crop calendar needs to be modified if the same trend is to be stable and prolonged.

\section{ACKNOWLEDGEMENT}

The authors are grateful to the anonymous reviewers for valuable suggestions in improving the paper.

\section{REFERENCES}

Chatfield, C. (2003). The Analysis of Time Series-An Introduction. CRC Press, Florida.

Dai, A., Fung, I. Y. and Del Genio, A. D. (1997). Surface observed global land precipitation variations during 1900-1988. J. Climate, 10(11): 2943-2962.

Dash, S. K., Jenamani, R. K., Kalsi, S. R. and Panda, S. K. (2007). Some evidence of climate change in twentiethcentury India. Climatic Change, 85(3-4): 299-321.

Dore, M. H. (2005). Climate change and changes in global precipitation patterns: What do we know? Environ. Int., 31(8): 1167-1181.

Gilbert, R. O. (1987). Statistical Methods for Environmental Pollution Monitoring. John Wiley \& Sons, New York.

Guhathakurta, P. and Rajeevan, M. (2008). Trends in the rainfall pattern over India. Int. J. Climatol., 28(11): 1453-1469. 
Table 4. Sen's slope (Q) (mm/year), $\tau$ and Z statistics of M-K test for district-wise seasonal and annual rainfall of GWB.

\begin{tabular}{|c|c|c|c|c|c|c|}
\hline District & Test Value & Pre-monsoon & Monsoon & Post-monsoon & Winter & Annual \\
\hline \multirow[t]{3}{*}{ Bankura } & $\mathrm{Q}$ & -0.190 & 1.814 & 0.418 & -0.021 & 1.558 \\
\hline & $\tau$ & -0.055 & 0.151 & 0.119 & -0.020 & 0.103 \\
\hline & Z & -0.810 & 2.216 & 1.751 & -0.289 & 1.510 \\
\hline \multirow[t]{3}{*}{ Birbhum } & Q & 0.014 & 1.338 & 0.414 & 0.010 & 1.856 \\
\hline & $\tau$ & 0.005 & 0.112 & 0.124 & 0.013 & 0.114 \\
\hline & Z & 0.077 & 1.653 & 1.829 & 0.188 & 1.671 \\
\hline \multirow[t]{3}{*}{ Burdwan } & $\mathrm{Q}$ & -0.839 & 0.398 & -0.039 & -0.008 & -0.795 \\
\hline & $\tau$ & -0.213 & 0.045 & -0.013 & -0.014 & -0.059 \\
\hline & $\mathrm{Z}$ & -3.136 & 0.661 & -0.194 & -0.197 & -0.864 \\
\hline \multirow[t]{3}{*}{ East Midnapore } & Q & -0.031 & 1.547 & 0.431 & -0.026 & 1.844 \\
\hline & $\tau$ & -0.010 & 0.131 & 0.085 & -0.026 & 0.122 \\
\hline & $\mathrm{Z}$ & -0.140 & 1.930 & 1.254 & -0.378 & 1.796 \\
\hline \multirow[t]{3}{*}{ Hooghly } & $\mathrm{Q}$ & -0.113 & 1.160 & 0.257 & 0.026 & 1.204 \\
\hline & $\tau$ & -0.023 & 0.098 & 0.060 & 0.024 & 0.078 \\
\hline & Z & -0.342 & 1.441 & 0.876 & 0.351 & 1.147 \\
\hline \multirow[t]{3}{*}{ Howrah } & Q & -0.155 & 0.574 & 0.092 & -0.070 & 0.193 \\
\hline & $\tau$ & -0.035 & 0.047 & 0.033 & -0.070 & 0.011 \\
\hline & Z & -0.513 & 0.691 & 0.480 & -1.023 & 0.161 \\
\hline \multirow[t]{3}{*}{ Kolkata } & $\mathrm{Q}$ & -0.192 & 1.363 & 0.859 & 0.657 & 1.947 \\
\hline & $\tau$ & -0.039 & 0.097 & 0.163 & 0.030 & 0.125 \\
\hline & $\mathrm{Z}$ & -0.566 & 1.430 & 2.400 & 0.444 & 1.843 \\
\hline \multirow[t]{3}{*}{ Murshidabad } & Q & -0.141 & 1.622 & 0.166 & -0.005 & 1.378 \\
\hline & $\tau$ & -0.041 & 0.132 & 0.048 & -0.010 & 0.087 \\
\hline & $\mathrm{Z}$ & -0.596 & 1.945 & 0.697 & -0.146 & 1.284 \\
\hline \multirow{3}{*}{ Nadia } & Q & -1.086 & -0.844 & -0.080 & -0.073 & -1.789 \\
\hline & $\tau$ & -0.216 & -0.063 & -0.025 & -0.072 & -0.096 \\
\hline & $\mathrm{Z}$ & -3.175 & -0.920 & -0.360 & -1.057 & -1.412 \\
\hline \multirow[t]{3}{*}{ N 24 Parganas } & Q & -0.367 & 1.864 & 0.300 & 0.028 & 1.773 \\
\hline & $\tau$ & -0.067 & 0.142 & 0.065 & 0.024 & 0.118 \\
\hline & $\mathrm{Z}$ & -0.983 & 2.088 & 0.950 & 0.349 & 1.739 \\
\hline \multirow[t]{3}{*}{ Purulia } & Q & 0.189 & 0.030 & 0.398 & -0.076 & 0.345 \\
\hline & $\tau$ & 0.057 & 0.003 & 0.120 & -0.069 & 0.024 \\
\hline & $\mathrm{Z}$ & 0.843 & 0.048 & 1.766 & -1.013 & 0.345 \\
\hline \multirow[t]{3}{*}{ S 24 Parganas } & Q & 0.357 & 4.372 & 0.848 & 0.000 & 4.990 \\
\hline & $\tau$ & 0.066 & 0.275 & 0.137 & 0.002 & 0.270 \\
\hline & Z & 0.974 & 4.056 & 2.022 & 0.033 & 3.976 \\
\hline \multirow[t]{3}{*}{ West Midnapore } & Q & 0.418 & 1.612 & -0.034 & -0.059 & 1.466 \\
\hline & $\tau$ & 0.096 & 0.146 & -0.009 & -0.041 & 0.115 \\
\hline & Z & 1.409 & 2.147 & -0.125 & -0.596 & 1.695 \\
\hline Month & \multicolumn{2}{|c|}{ Increasing (I) / Decreasing (D) } & \multicolumn{4}{|c|}{ District/GWB } \\
\hline March & \multicolumn{2}{|r|}{$\mathrm{D}$} & \multicolumn{4}{|l|}{ Nadia } \\
\hline April & & $\mathrm{D}$ & Nadia & & & \\
\hline May & & $\mathrm{D}$ & Burdwan & & & \\
\hline July & & $\mathrm{I}$ & Murshida & & & \\
\hline August & & I & South 24 & zanas & & \\
\hline September & & I & $\begin{array}{l}\text { Bankura, } \\
24 \text { Pargaı }\end{array}$ & $\begin{array}{l}\text { hum, East Midnap } \\
\text { South } 24 \text { Parganas }\end{array}$ & GWB, H & rah, North \\
\hline October & & I & Kolkata, & h 24 Parganas & & \\
\hline November & & I & East Mid & & & \\
\hline December & & $\mathrm{I}$ & Birbhum, & wrah & & \\
\hline Annual/Seasona & & & & & & \\
\hline Pre-monsoon & & $\mathrm{D}$ & Nadia, B & & & \\
\hline Monsoon & & I & $\begin{array}{l}\text { Bankura, } \\
\text { West Mic }\end{array}$ & $\begin{array}{l}\text { B, North } 24 \text { Parga } \\
\text { ore }\end{array}$ & , South 24 & rganas, \\
\hline Post-monsoon & & I & Kolkata, & h 24 Parganas & & \\
\hline Annual & & I & $\mathrm{GWB}, \mathrm{So}$ & 24 Parganas & & \\
\hline
\end{tabular}


Helsel, D. R. and Hirsch, R. M. (1992). Statistical Methods in Water Resources. Elsevier, Amsterdam.

Jain, S. K., Kumar, V. and Saharia, M. (2013). Analysis of rainfall and temperature trends in northeast India. Int. J. Climatol., 33(4): 968-978.

Kendall, M. G. (1975). Rank Correlation Methods. Charles Griffin, London.

Krishnakumar, K. N., Rao, G. P. and Gopakumar, C. S. (2009). Rainfall trends in twentieth century over Kerala, India. Atmos. Environ., 43(11): 1940-1944.

Kumar, K. R., Pant, G. B., Parthasarathy, B. and Sontakke, N. A. (1992). Spatial and subseasonal patterns of the long-term trends of Indian summer monsoon rainfall. Int. J. Climatol., 12(3): 257-268.

Kumar, V., Jain, S. K. and Singh, Y. (2010). Analysis of long-term rainfall trends in India. Hydrol. Sci. J., 55(4): 484-496.

Kumar, V. and Jain, S. K. (2011). Trends in rainfall amount and number of rainy days in river basins of India (19512004). Hydrol. Res., 42(4): 290-306.

Kumar, A., Chattopadhyay, C., Singh, K. N., Vennila, S. and Rao, V. (2014). Trend analysis of climatic variables in Pegionpea growing regions in India. MAUSAM, 65(2): 161-170.

Mann, H. B. (1945). Nonparametric tests against trend. Econometrica, 13(3): 245-259.

Mondal, A., Kundu, S. and Mukhopadhyay, A. (2012). Rainfall trend analysis by Mann-Kendall test: a case study of north-eastern part of Cuttack district, Orissa. Int. J. Geol. Earth Environ. Sci., 2(1): 70-78.

Mooley, D. A. and Parthasarathy, B. (1984). Fluctuations in all-India summer monsoon rainfall during 1871-1978. Climatic Change, 6(3): 287-301.

Mozejko, J. (2012). Detecting and Estimating Trends of Water Quality Parameters. Water Quality Monitoring and Assessment, Dr. Voudouris (ed.), InTech, pp. 95120.

New rainfall series for the districts, meteorological subdivisions and country as whole of India. (2011). National Climate Centre Research Report No: 2/2011, Sept.

Parthasarathy, B. (1984). Interannual and long-term variabil- ity of Indian summer monsoon rainfall. Proc. Indian Acad. Sci. (Earth Planet. Sci.), 93(4): 371-385.

Patle, G. T. and Libang, A. (2014). Trend analysis of annual and seasonal rainfall to climate variability in North-East region of India. Journal of Applied and Natural Science, 6(2): 480-483.

Salmi, T., Määttä, A., Anttila, P., Ruoho-Airola, T. and Amnell, T. (2002). Detecting trends of annual values of atmospheric pollutants by the Mann-Kendall test and Sen's slope estimates - the Excel template application MAKESENS. Publication on Air Quality, Finnish Meteorological Institute, no. 31 .

Schertz, T. L., Alexander, R. B. and Ohe, D. J. (1991). The computer program estimate trend (ESTREND), a system for the detection of trends in water-quality data. U.S. Geological Survey Water-Resources Investigations Report, 91-4040, pp. 63.

Sen, P. K. (1968). Estimates of the Regression Coefficient Based on Kendall's Tau. J. Am. Stat. Assoc., 63: 13791389.

Singh, N. and Sontakke, N. A. (2002). On Climatic Fluctuations and Environmental Changes of the Indo-Gangetic Plains, India. Climatic Change, 52(3): 287-313.

Singh, P., Kumar, V., Thomas, T. and Arora, M. (2008). Changes in rainfall and relative humidity in different river basins in the northwest and central India. Hydrol. Process., 22(16): 2982-2992.

Srivatsava, H. N., Dewan, B. N., Dikshit, S. K., Prakasa Rao, G. S., Singh, S. S. and Rao, K. R. (1992). Decadal trends in climate over India. MAUSAM, 43(1): 7-20.

Thapliyal, V. and Kulshrestha, S.M. (1991). Climate changes and trends over India. MAUSAM, 42(4): 333-338.

Theil, H. (1950). A rank-invariant method of linear and polynomial regression analysis (parts 1-3). Ned. okad. Wetensch. Proc. ser. A, 53: 386-392, 521-525, 1397. 1412.

Yue, S., Pilon, P. and Phinney, B. (2003). Canadian streamflow trend detection: impacts of serial and crosscorrelation. Hydrolo. Sci. J., 48(1): 51-63. 